\title{
Burden of Mild Mental Retardation attributed to prenatal methylmercury exposure in Amazon: local and regional estimates
}

\author{
Carga de Retardo Mental Leve atribuída à exposição pré-natal \\ ao metilmercúrio na Amazônia: estimativas local e regional
}

Ana Claudia Santiago de Vasconcellos ${ }^{1}$

Paulo Rubens Guimarães Barrocas ${ }^{1}$

Claudia Maribel Vega Ruiz ${ }^{2}$

Dennys de Souza Mourão ${ }^{2}$

Sandra de Souza Hacon ${ }^{2}$

${ }^{1}$ Departamento de Saneamento e Saúde Ambiental, Escola Nacional de Saúde Pública Sergio Arouca, Fundação Oswaldo Cruz. Rua Leopoldo Bulhões 1480, Manguinhos. 21041-210 Rio de Janeiro RJ Brasil. anacsvasconcellos@ gmail.com

${ }^{2}$ Departamento de Endemias, ENSP, Fiocruz. Rio de Janeiro RJ Brasil.

\begin{abstract}
The gold rush in the Amazon Region caused an increase of mercury $(\mathrm{Hg})$ levels in the environment, and, consequently, raised human exposure. Once released into aquatic systems, $\mathrm{Hg}$ could generate methylmercury $(\mathrm{MeHg})$, an extremely toxic compound, which is accumulated through trophic chains. Several studies have provided evidences of the brain sensitivity to $\mathrm{MeHg}$, as well as, of the fetus vulnerability during pregnancy. The main objective of this study was to estimate the Mild Mental Retardation (MMR) in Amazonian populations, caused by prenatal exposure to $\mathrm{MeHg}$, using the methodology proposed by Poulin (2008), which quantifies the environmental burden of disease. The estimates of the MMR burden, attributed to prenatal $\mathrm{MeHg}$ exposure, were based on the calculation of Disability-Adjusted Life Years (DALY), which were obtained from MMR incidence rate in the studied populations. At the local level, the MMR incidence rate calculations were based on primary data of $\mathrm{MeHg}$ exposure of riverine women at childbearing age. The MMR incidence rate was equal to 5.96/1,000 infants, which would result in 2.0 IQ points loss in $34.31 \%$ of the newborns. The estimated DALY/1,000 infants was equal to 71.2, while the DALY was 576. For the regional estimates, different exposure scenarios were created. The calculated DALY varied from 3,256 to 65,952 per year.
\end{abstract}

Key words $\mathrm{Hg}, \mathrm{DALY}$, Amazon
Resumo A corrida pelo ouro na Amazônia elevou os níveis de mercúrio $(\mathrm{Hg})$ no ambiente e, consequentemente, aumentou a exposição humana. Uma vez liberado em sistemas aquáticos, o $\mathrm{Hg}$ pode gerar metilmercúrio $(\mathrm{MeHg})$, um composto tóxico que se acumula ao longo de cadeias tróficas. Vários estudos têm gerado evidências sobre a sensibilidade do cérebro ao $\mathrm{MeHg}$, bem como sobre a vulnerabilidade do feto durante a gravidez. $O$ principal objetivo deste trabalho foi estimar a carga de Retardo Mental Leve (RML) em populações amazônicas, causada pela exposição pré-natal ao $\mathrm{MeHg}$, utilizando a metodologia proposta por Poulin (2008). As estimativas de RML, atribuída à exposição ao $\mathrm{MeHg}$ pré-natal, foram baseadas no cálculo dos Anos de Vida Ajustados por Incapacidade (DALY), que foi desenvolvido a partir de taxa de incidência RML nas populações estudadas. Em nível local, o cálculo da taxa de incidência RML baseou-se em dados primários sobre a exposição ao $\mathrm{MeHg}$ em mulheres ribeirinhas em idade fértil. A taxa de incidência RML foi igual a 5,96/1.000 nascidos, o que resulta na perda de 2,0 pontos de QI em 34,31\% dos nascidos. A estimativa de DALY/1.000 nascidos foi igual a 71,2, enquanto o DALY foi de 576. Para as estimativas regionais, foram criados diferentes cenários de exposição. Os DALYs calculados variaram de 3.256 a 65.952 por ano.

Palavras-chave $H g, D A L Y$, Amazônia 


\section{Introduction}

In 2015, the Blacksmith Institute classified mercury $(\mathrm{Hg})$ as the third most dangerous environmental pollutant for human health. According to their last report, 19 million people are at risk worldwide due to $\mathrm{Hg}$ exposure and the main global source of $\mathrm{Hg}$ emissions is the artisanal gold mining ${ }^{1}$. In Brazil, the $\mathrm{Hg}$ environmental pollution is concentrated in the Amazon Region, despite the existence of many diffuse contamination sources all over the country ${ }^{2}$. Some studies have shown that about a hundred tons of metallic mercury $\left(\mathrm{Hg}^{0}\right)$ were released in the Madeira river basin by artisanal gold mining between 1979 and $1990^{3,4}$. Once released into aquatic systems, $\mathrm{Hg}$ becomes readily available for chemical transformations that could generate methylmercury ( $\mathrm{MeHg}$ ), an extremely toxic $\mathrm{Hg}$ species $^{5}$.

$\mathrm{MeHg}$ is a mercury-organic compound, which is easily assimilated and accumulated through aquatic trophic chains, due to its lipophilic nature ${ }^{6}$. This phenomenon might cause serious impacts in the riverine Amazonian populations, which have freshwater fishes as main protein source in their diet. These communities can be considered as particularly vulnerable to $\mathrm{MeHg}$ exposure .

The scientific literature of the past few decades have pointed out that the growing use of $\mathrm{Hg}$ in many anthropic activities has increased its availability in the environment and, consequently, human exposure ${ }^{8-10}$. Therefore, $\mathrm{Hg}$ exposure became a significant Public Health issue at a global scale. Several studies have provided evidences of the central nervous system sensitivity to $\mathrm{MeHg}^{11,12}$, as well as, of the fetus vulnerability during pregnancy ${ }^{13}$. Therefore, the consumption of fish and other aquatic organisms, with high $\mathrm{Hg}$ levels, can be dangerous for women during pregnancy, since the development of the brain could have been compromised ${ }^{14}$.

One of the consequences of human brain exposure to MeHg is cognitive damages, which can cause loss of intelligence and mental retardation. According to the American Association of Mental Retardation, this diagnosis is configured when the individual has a low IQ and adaptive injury. There are different levels of mental retardation and it is estimated that $85 \%$ of cases are of mild type (MMR), which has an idiopathic nature in most cases. The MMR is considered one of the most common psychiatric disorders in children and adolescents, with prevalence ranging from 1 to $3 \%$ in the population ${ }^{15}$.
One possible way to assess the human health impact due to $\mathrm{Hg}$ exposure is estimate the environmental burden of disease (EBD) attributed to this risk factor. The EBD is a component of the burden of disease (BoD) approach, which considers the health impact caused by environmental risk factors. The disease burden is a measure used to quantify the gap between an ideal situation, which everybody lives in perfect health conditions until an old age, and the actual situation, which individuals lose health, or even their life, for several reasons, such as, traffic accidents, infections and intoxications ${ }^{16,17}$.

This estimative is a key information for decision-making process, establishment of priorities, and management of financial resources for scientific research investments or intervention actions ${ }^{18}$. Currently, the measure used to quantify the BoD is the Disability Adjusted Life Years (DALY), which it is an indicator of the population's health status ${ }^{17,19,20}$.

The Amazon populations are exposed to many risk factors besides $\mathrm{Hg}$, such as, inadequate sanitation, limited access to safe drinking water, high infectious (e.g. AIDS, tuberculosis, syphilis) and endemic diseases (e.g. malaria, dengue) incidences $^{21}$. Therefore, it is important to develop studies to estimate the health loss that can be attributed to $\mathrm{Hg}$ exposure only. These results can be used to set priorities and develop public health policies to prevent and control $\mathrm{Hg}$ exposure.

The main objective of this paper was to estimate the health impact caused by prenatal exposure to $\mathrm{MeHg}$ in riverine Amazonian populations, using methods to quantify the EBD attributable to this risk factor, following the approach proposed by the World Health Organization ${ }^{22}$.

\section{Methods}

The methodology used to estimate the Hg EBD followed the Exposure-based Approach that is based on $\mathrm{MeHg}$ exposure distribution in the population $^{23}$. For this analysis, we used DALY as the health status indicator of the population and two spatial levels: Local and Regional.

The MMR endpoint was used to quantify the EBD, attributable only to prenatal exposure to $\mathrm{MeHg}$, as proposed by Axelrad et al. ${ }^{24}$. For the local analysis, MeHg exposure data was obtained from a cross-sectional study (i.e. the survey was applied to riverine communities of the Madeira River basin). While, for the regional estimates, available data from several studies conducted along of the Amazon region were used. 


\section{Data collection to calculate the local estimates}

Hair samples were collected from childbearing age women ${ }^{25}$ (i.e. from 15 to 49 years old) from communities located in the Madeira River Basin in two sampling campaigns (May 2009 and April 2011). The hair was chosen as MeHg biomarker because there is plenty of evidence of a direct correlation between $\mathrm{Hg}$ levels in hair (total $\mathrm{Hg}$ ) and $\mathrm{MeHg}$ intake from diet.

The inclusion criteria for this cross-sectional study were: (i) to live in communities located on the banks of the Madeira River Basin for at least 12 months; (ii) to agree to participate in the study, by signing the term of consent form, and (iii) to agree to sample collection. The research protocol and the adopted procedures were reviewed and approved by the Ethics Committee of the National School of Public Health at the Oswaldo Cruz Foundation.

Total $\mathrm{Hg}$ concentration (hair-Hg) was determined in individual hair samples according to routine laboratory procedures at the Wolfgang Christian Pfeiffer Environmental Biogeochemical Laboratory (BIOGEOQ), at the Federal University of Rondônia ${ }^{3}$. Briefly, after mineralization in acid-oxidant medium, total $\mathrm{Hg}$ determination was performed by cold vapor atomic absorption spectrometry on a Perkin-Elmer (Ueberlingen, Germany) FIMS- $400^{\circledR}$ instrument. For quality control, all analytical runs included material certified by the International Atomic Energy Agency (IAEA-085 and IAEA-086). Recovery rates were above $80 \%$ and detection limit below 0.03 $\mathrm{mg} \cdot \mathrm{kg}-1$.

\section{Data collection to calculate the regional estimates}

Poulin \& $\mathrm{Gibb}^{22}$ calculated the EBD, related to $\mathrm{Hg}$ exposure, using data from literature. The data about $\mathrm{MeHg}$ exposure in regional level was obtained through literature review using scientific databases (i.e. PubMed and Web of Science). The keywords used in the "topic" field search were "hair", "mercury" OR "methylmercury" and "Amazon". The purpose of this search was to identify scientific articles, which contained information about the distribution of $\mathrm{Hg}$ levels in hair samples of the female population that lives in the Amazon region, especially, of childbearing age. Other inclusion criteria included articles published in Portuguese or Spanish or English; original research articles published in peer-reviewed journals in the last 10 years, which full text were available for downloading.

\section{MMR MeHg-attributed}

Considering that $\mathrm{MeHg}$ affects mainly the central nervous system and that the fetal stage is the most vulnerable period for xenobiotic exposure, a significant health outcome (endpoint) associated with this risk factor is the children cognitive impairment caused by prenatal $\mathrm{MeHg}$ exposure $^{24,26,27}$.

This health endpoint can be measured using the child's intelligence quotient, which, in turn, can be assessed using IQ tests to identify IQ losses. Since, IQ deficit is not considered a disease itself, the outcome associated with prenatal exposure to MeHg is the Mild Mental Retardation (MMR), as a result of IQ loss. This is the only health outcome consider to calculate the EBD attributable to prenatal $\mathrm{MeHg}$ exposure and the single dose-response relationship described in the literature related to $\mathrm{MeHg}$ exposure ${ }^{24}$. This relationship states that for each $1.0 \mu \mathrm{g} / \mathrm{g}$ of $\mathrm{Hg}$ in the mother's hair causes of 0.18 IQ points loss in the unborn children. It assumes a positive linear association (with no threshold) between IQ loss and hair $\mathrm{Hg}$ levels in pregnant women.

Furthermore, we must consider that intelligence in a human population approaches a normal distribution with a mean of 100 IQ points and a standard deviation of 15 IQ points. The MMR occurs when the IQ score is between 50 and 70 IQ points ${ }^{28}$. The number of children, who will belong to the MMR group, due to maternal $\mathrm{MeHg}$ exposure, is estimated by the arithmetic mean and standard deviation of the Hg levels detected in the hair of the studied population ${ }^{22}$.

\section{Method to estimate the Burden of MMR attributed to Prenatal MeHg Exposure}

The health status indicator chosen to estimate the burden of MMR attributed to $\mathrm{MeHg}$ was DALY. The DALY is the sum of years of life lost due to premature death (Years Life Lost YLL) and years lived with disability (Years Lived with Disability - YLD) ${ }^{16}$.

The parameters used to calculate the DALYs attributed to prenatal $\mathrm{MeHg}$ exposure are Age Weight ( $100 \%$ or 1$)$; Discount rate (3\%); MMR; Disease Weight (0.361); illness duration (i.e. equivalent to the standard of living expected for men and for women, 80 and 82.5 years, respectively $)^{29}$. 
The age weight reflects the differences of productivity during a person's life, attributed by the society. For example, a lower value is attributed to the years of childhood or older age, due to a lower productivity during these life stages. The age weight varies from 0 (no weight) to 1 (100 $\%)$. In the MMR endpoint, attributable to $\mathrm{MeHg}$ exposure, an age weight equivalent to $100 \%$ (or 1 ) is used, because this health outcome extends throughout the whole individual's life. This methodology assumes that the injury caused by $\mathrm{MeHg}$ in the fetal brain is irreversible, and thus, the loss of intelligence (IQ loss) is constant during the entire life ${ }^{22}$.

Yet, there is no disease weight (DW) developed specifically for the MMR induced by $\mathrm{MeHg}$ exposure. Thus, the DW of the MMR induced by lead, which is equal to 0.361 , have been used for the DALY calculation of MMR attributed to prenatal MeHg exposure ${ }^{29}$.

In addition, the calculation of DALYs requires the use of a discount rate of $3 \%$ for each year of life lost in the future. This discount rate is commonly used in statistical analysis, assigning less value to life years lost in the future than to the life years lost in the present ${ }^{17}$.

The MMR incidence rate per 1,000 infants is calculated from the arithmetic mean and standard deviation of the concentrations of $\mathrm{Hg}$ in the hair of women of childbearing age. While the healthy life lost years due to this inability (DALY) is estimated by the MMR incidence rate and number children born in the studied population. In this case, the DALY is equal to the YLD (Years Lived with Disability) once the MMR does not cause the death of the individuals affected.

The calculations were performed using customized MS Excel spreadsheets used by the $\mathrm{WHO}^{22}$ and provided by A Prüss-Üstün (personal communication). One of the spreadsheets estimates the percentage of infants that loses about 2.0 IQ points, and the MMR incidence rate per 1000 infants. While, the second worksheet calculates the DALY based on the incidence rate and the number of infants born in the studied community.

In the first spreadsheet, the Excel NORMDIST function is used to determine the proportion of the population with $\mathrm{Hg}$ levels in hair above 10 $\mu \mathrm{g} / \mathrm{g}$, which it is assumed to lose 1.98 IQ points, considering the dose-response relationship proposed by Axelrad et al. ${ }^{24}$. The NORMDIST function $(\mathrm{x}, \mu, \delta$, cumulative) shows the probability of an observed value from a random variable, normally distributed with an average $\mu$ and standard deviation $\delta$, would be less than or equal to $\mathrm{x}$. The last argument of the function is set to be true or equal to one, to obtain the cumulative probability curve. Therefore, 1 - NORMADIST $(\mathrm{x}, \mu, \delta, 1)$ calculates the cumulative proportion of a population with values above the lower limit (x), for a given range of $\mathrm{Hg}$ concentrations. It is important to note that this type of analysis assumes that the distribution of $\mathrm{Hg}$ levels in exposed population hair is normal, as the distribution of intelligence (IQ) in any human population.

\section{Local estimates of disease burden}

To estimate the EBD at the local level, mean values and standard deviations of $\mathrm{Hg}$ concentrations in hair samples from women in childbearing age, which live in the Madeira River Basin, were used. To calculate the DALY (DALY/1,000 infants and the total DALYs), we used the number of live births in the city of Porto Velho (RO) in 2010, according to data available in DATASUS (Brazilian Health Information System) for the sampling period.

\section{Regional estimates of disease burden}

The regional estimates were based on the average values and standard deviations of $\mathrm{Hg}$ concentrations in hair of all studies developed in the Amazon region that were identified during the literature review. For each of the located articles were estimated: (i) Percentage of infants who loses 2.0 IQ points; (ii) MMR incidence rate and (iii) DALY/1,000 infants. According to the results obtained, three different exposure scenarios were developed to represent possible exposure range at the regional level. The number of live births in the North region of Brazil (i.e. Amazon Region), available in DATASUS for the year 2010, was used to calculate the regional DALY.

\section{Construction of Alternative Scenarios and Counterfactual Analysis}

According to the methodology proposed by Murray \& Lopez ${ }^{16}$ to quantify the BoD in general populations, it is important to create alternative scenarios representing situations where the risk factor in question may be increased, reduced or absent. Therefore, three different exposure scenarios to MeHg (Best, Intermediate and Worst Case Scenario) were developed. They were constructed based on the Hg hair concentrations observed in the literature review. 


\section{Results}

\section{Local Burden of MMR}

Total number of 462 women of childbearing-age from Madeira River communities participated in this study. Table 1 shows the total $\mathrm{Hg}$ concentrations detected in their hair samples and the estimated MMR related to the Hg exposure level observed.

Based on the mean value and the standard deviation of $\mathrm{Hg}$ hair concentrations as equal to $6.49 \mu \mathrm{g} / \mathrm{g}$ and 8.69 , respectively, it was estimated that $34.31 \%$ of the children born would lose about 2.0 IQ points. Therefore, it was estimated that 2,775 children, born in the year 2010 , would have a 2.0 IQ points deficit due to maternal exposure to $\mathrm{MeHg}$, considering the number of births equal to 8,089 . In another way, this estimate corresponds to 5,550 IQ points lost in these communities in 2010. The MMR incidence rate in this population was estimated as 5.96/1,000 infants, resulting in 71.2 DALYs/1,000 infants, due to MMR induced by MeHg, and a total DALY equal to 576 .

\section{Regional Burden of Mild Mental Retardation (Amazon Region)}

Table 2 shows the Hg exposure data in the Amazon region, based on 18 scientific articles identified in the literature review. In addition, it was included the data from the Madeira river basin (described in the previous section) to calculate the Regional Burden of Disease.

Because of the large range of $\mathrm{Hg}$ levels detected in hair samples of Amazonian populations studied, the estimates of the EBD in the Amazon Region were calculated using three different exposure scenarios, as counterfactual analysis. Into this perspective, the "Best Scenario" was the $\mathrm{Hg}$ low exposure level (i.e. $<1 \mu \mathrm{g} / \mathrm{g}$ ), where no relevant health effects were expected. In the "Intermediate Scenario", the Hg exposure levels were above the "Best Scenario" but below $10 \mu \mathrm{g} / \mathrm{g}$, considered as the threshold for the emergence of neurological damages in the unborn child ${ }^{30}$. In the "Worst Case Scenario", the average Hg exposure levels were above $10 \mu \mathrm{g} / \mathrm{g}$.

The estimates were calculated considering the number of children born in the north region of Brazil, according to DATASUS data for the year 2010. Table 3 presents the estimates for each scenario. The "Best Scenario" was constructed using exposure data observed in women that lives
Table 1. Burden of MMR attributed to MeHg, local estimates (Madeira River Basin).

\begin{tabular}{lrlr}
\hline \multicolumn{1}{c}{$\begin{array}{c}\text { Mercury Levels } \\
\text { Distribution }(\mu \mathrm{g} / \mathrm{g})\end{array}$} & \multicolumn{2}{c}{$\begin{array}{c}\text { MMR attributed to MeHg } \\
\text { (Madeira River Basin) }\end{array}$} \\
\hline $\begin{array}{l}\text { Number of woman } \\
\text { of childbearing age } \\
(15-49 \text { years old })\end{array}$ & 462 & $\begin{array}{l}\text { Number live } \\
\text { births (2010 } \\
\text { year) }\end{array}$ & $8.089^{*}$ \\
Mean & 6,49 & $\begin{array}{l}\text { \% loss 2pts IQ } \\
\text { (number) }\end{array}$ & $\begin{array}{r}34,31 \\
(2.775)\end{array}$ \\
Standard- & 8,69 & $\begin{array}{l}\text { Incidence Rate } \\
\text { of MML / }\end{array}$ & 5,96 \\
desviation & & $\begin{array}{l}1,000 \text { infants } \\
\text { DALY (YLD) }\end{array}$ & 576 \\
Range & $0,02-$ & \\
Median & 71,73 & DALY/1,000 & 71,2 \\
& 4,03 & inhabitants & \\
\hline
\end{tabular}

in the municipality of Alta Floresta ${ }^{31}$, which $\mathrm{Hg}$ average level was below $2.0 \mu \mathrm{g} / \mathrm{g}$. This concentration is considered normal for populations that have a low fish diet, according to $\mathrm{WHO}^{30}$. In this case, the MMR incidence rate was $0.89 / 1,000$ infants, which results in 10.6 DALYs/1,000 infants and a total DALY of 3,256 . This scenario did not predict a decrease in IQ score for this population.

The "Intermediate Scenario" was built with the Madeira River basin information, presented in this study. In this scenario, the mean $\mathrm{Hg}$ concentration was $6.49 \mu \mathrm{g} / \mathrm{g}$. Even though, this average was below the $10 \mu \mathrm{g} / \mathrm{g}$ limit, it was predicted a 210,267 IQ points loss in a year. Furthermore, the estimated number of children born, who would lose 2.0 IQ points, was equal to 105,133 per year $(34.31 \%)$. The MMR incidence rate was calculated as 5.96/1,000 infants, resulting in 71.1 DALYs/1,000 infants, and a total DALY equal to 21,801

The "Worst Case Scenario" was based on the data presented by Santos et al. ${ }^{32}$. They studied the São Luiz do Tapajós population, whose average $\mathrm{Hg}$ hair concentration was $19.91 \mu \mathrm{g} / \mathrm{g}$, almost two times the WHO limit. It was estimated that almost $80 \%$ of the children born would lose 2.0 points in IQ scale. This percentage corresponds to the birth of 244,004 children each year with a deficit of 2.0 IQ points. As a whole, the Amazon region would lose 500,000 IQ points. The MMR incidence rate was estimated as $18.03 / 1,000$ infants, resulting in 215.2 DALYs/1,000 infants and a total DALY equal to 65,952 . 


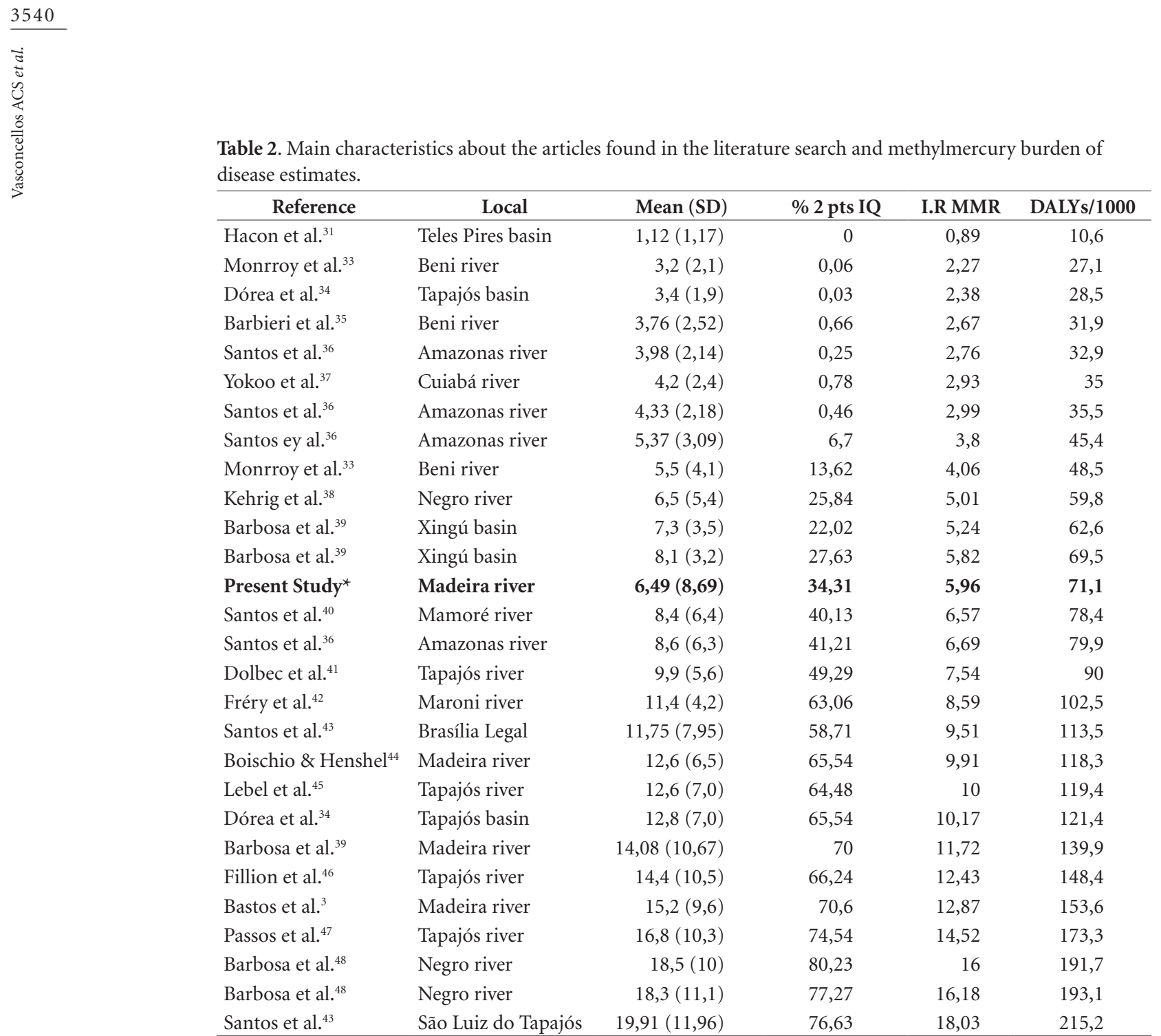

Table 3. MMR attributed to MeHg in three different exposure scenarios. (Counterfactual Analysis).

\begin{tabular}{|c|c|c|c|}
\hline & $\begin{array}{l}\text { "Best Scenario" } \\
\left(\text { Hacon et al. }{ }^{31}\right) \\
\text { Mean } \leq 2,0 \mu \mathrm{g} / \mathrm{g}\end{array}$ & $\begin{array}{c}\text { "Intermediate Scenario" } \\
\text { (Present work / Local } \\
\text { estimate) } \\
2<\text { Mean } \leq 10 \mu \mathrm{g} / \mathrm{g} \\
\end{array}$ & $\begin{array}{c}\text { "Worst Scenario" } \\
\left(\text { Santos et al. } .^{43}\right) \\
\text { Mean > } 10 \mu \mathrm{g} / \mathrm{g}\end{array}$ \\
\hline Mean & $1,12 \mu \mathrm{g} / \mathrm{g}$ & $6,49 \mu \mathrm{g} / \mathrm{g}$ & $19,91 \mu \mathrm{g} / \mathrm{g}$ \\
\hline Standard-desviation & $1,17 \mu \mathrm{g} / \mathrm{g}$ & $8,69 \mu \mathrm{g} / \mathrm{g}$ & $11,96 \mu \mathrm{g} / \mathrm{g}$ \\
\hline Incidence Rate of MMR/1,000 births & 0,89 & 5,96 & 18,03 \\
\hline DALY/1000 inhabitants & 10,6 & 71,1 & 215,2 \\
\hline DALY Total & 3.256 & 21.801 & 65.952 \\
\hline Number of Birth loss 2,0 pts de IQ (\%) & 0 & $105.133(34,31)$ & $244.004(79,63)$ \\
\hline IQ Loss Total Points & 0 & 210.267 & 488.007 \\
\hline
\end{tabular}

\section{Discussion and final remarks}

Despite of the ubiquitous presence of $\mathrm{Hg}$ in the Amazon region, comparing the different Amazo- nian populations shown in Table 2, we observed significant differences in their $\mathrm{Hg}$ exposure levels. A possible explanation for these differences is a variation in their eating habits. Even though, the 
Amazonian riverine communities consume the same basic food items (i.e. fish as the main protein source, manioc and other roots as energy source, and tropical fruits), these items vary seasonally (i.e. flood and dry periods) and spatially along the Amazon region. For example, the seasonality affects the availability of different fish species and their age/size, as well as, other food items, due to geographical isolation of riverine populations during the dry period. Thus, during this season, they cannot access large cities and their markets, the only source of certain food items. Furthermore, the proximity to gold mining areas, where $\mathrm{Hg}$ is used, it is also an important factor to determine the human exposure level ${ }^{44}$. The average $\mathrm{Hg}$ levels in hair samples, from Amazonian riverine communities used in this study, varied more than order of magnitude (i.e. from 1.12 to $19.91 \mu \mathrm{g} / \mathrm{g}$ ). Consequently, the calculated rates differed from 10.6 to 215.2 DALYs/1,000 infants, depending of $\mathrm{Hg}$ exposure level considered. This variability in the Hg exposure levels, among Amazonian riverine communities, was also reported by Barbieri \& Gordon ${ }^{49}$. According to their review, Hg levels in hair of riparian communities could vary from 1.1 to $34.2 \mu \mathrm{g} / \mathrm{g}$, which is very similar to the range obtained in this study.

Considering the DALY/1,000 infants rates estimated in this study, we calculated a rate of 71.2 DALYs/1,000 infants in the population of the Madeira River Basin (i.e. Local Burden of Disease), and Regional Burden of Disease rates ranging from 10.6 to 210 per 1,000 infants, depending on the exposure scenario considered (as described in the counterfactual analysis).

To assess the importance of $\mathrm{MeHg}$ as a risk factor for the Amazon's population health, it is necessary to compare the results obtained in this study to other estimates of burden of disease, associated with this and other environmental risk factors. However, until this manuscript was written, no other similar studies for the Amazon region were published. There are some articles about the burden of disease in Brazil ${ }^{50-52}$. Yet, they could not be used to discuss our results due to important methodological differences. While the environmental burden of disease study follow the approach based on the exposure distribution of the risk factor, other burden of disease studies follow the approach based on the health outcome, which it is obtained from morbidity and/ or mortality data of the population studied ${ }^{53}$.

The only study published related to burden of disease attributed to $\mathrm{Hg}$ was done by Steckling et al. ${ }^{54}$. However, this work considered only the health problems caused by chronic exposure to elemental $\mathrm{Hg}\left(\mathrm{Hg}^{0}\right)$ in Zimbabwean miners. In this study, the individuals were subjected to occupational exposure through inhalation of metallic $\mathrm{Hg}$ vapors during the mining activity. Once inhaled, the elemental $\mathrm{Hg}$ vapor can reach the central nervous system, causing neurological disturbances comparable to those caused by alcohol abuse. The miners showed median of $\mathrm{Hg}$ in hair equal to $3 \mu \mathrm{g} / \mathrm{g}$ and maximum concentration equal to $112 \mu \mathrm{g} / \mathrm{g}$. According to this exposure profile, the burden of disease estimates were 8 DALYs/1,000 population, attributable to chronic metallic $\mathrm{Hg}$ intoxication from occupational exposure in 2004. Comparing these estimates with the present study, described in the counterfactual analysis for the Amazon region population, they were similar to our "Best Scenario" estimates (10.6 DALYs / 1000 infants). This comparison suggests that the problem of human exposure to $\mathrm{Hg}$ in the Amazon might be more serious than for miners in Zimbabwe, considering that "Best Scenario" is the lowest $\mathrm{Hg}$ exposure condition, and there are higher $\mathrm{Hg}$ exposure level, which resulted in higher burden of disease. Moreover, the neurological damage caused by $\mathrm{MeHg}$ to the fetus during pregnancy is more severe than the harm caused by the elemental $\mathrm{Hg}$ vapor to an adult brain.

Although, there were no articles published about mild mental retardation (MMR) attributed to $\mathrm{MeHg}$ exposure, there are three articles about MMR induced by lead. The latest study was developed by Caravanos et al. ${ }^{55}$ for the Mexican population. They estimated the MMR incidence rate equal to 5.98 per 1,000 children. In addition, lead exposure profile in this population indicates that $15 \%$ of children would lose 5.0 IQ points due to this risk factor. Norman et al. ${ }^{56}$ conducted a similar study for the South African population. Their estimated MMR incidence rate was 4.82/1,000 children. The MMR incidence rates obtained in these two articles were similar to the MMR incidence rate attributed to $\mathrm{MeHg}$ exposure conditions of the "Intermediate Scenario", which was equal to 5.96 per 1,000 children, but they were 3 times lower than "Worst case Scenario" estimate (i.e. 18.03 /1,000 children).

In Fewtrell et al. ${ }^{57}$ study, they estimated the global environmental burden of disease of MMR induced by lead. The data about lead exposure in populations living in different areas around the world were obtained from scientific databases. The exposure data were grouped according to the location of the studies. All continents were pres- 
ent in the studied sample. For the Latin American group, in which Brazil was included, a MMR incidence rate was estimated as 13.2/1,000 population. This incidence rate was a lot higher than the incidence rates estimated for the "Best and Intermediate Scenarios" of this study (i.e. 0.89 and $5.96 / 1,000$, respectively), but little lower than the "Worst Scenario" $(18.03 / 1,000)$ estimate.

It should be pointed out that the burden of disease estimated by the present study referred to only one Brazilian region (i.e. Amazon region), while the other studies discussed here used a national scale (except the Fewtrell's Global study). Therefore, data comparisons should be done with caution. There is no doubt about the severity of the MeHg environmental problem in the Amazon region. However, an extrapolation of this Amazon region estimate to the Brazilian national level might not be adequate because of the large differences in the $\mathrm{Hg}$ exposure levels among the Brazilian population. For instance, hair $\mathrm{Hg}$ concentrations in Amazonian riverine communities are often higher than the acceptable limit recommended by health agencies, while Hg levels from populations from other Brazilian regions were lower ${ }^{58,59}$. Nevertheless, studies of national scope are relevant, mainly for the identification of vulnerable population groups.

Considering that the burden of disease method is under construction, it is necessary to develop strategies to reduce its uncertainties, such as studies of human biomonitoring, development of discount rates that reduce the influence of co-morbidities and multi-causalities in health outcomes. Moreover, it is necessary to invest in the development of health surveillance strategies for population exposed chronically to low doses of pollutants, and finally, the production of diagnostic protocols internationally accepted, allowing for early identification of individuals committed by prenatal exposure to $\mathrm{MeHg}$.

On the other hand, this methodology employs the DALY unit as a health indicator. It is an important and innovative approach, since it aggregates different health measures such as mortality and morbidity simultaneously. In addition, DALY estimate express the severity, the magnitude and duration of the injury, all at once. This measurement enables a robust way to compare health impacts caused by different environmental factors. However, this populational health status indicator has limitations also. The DALY calculations simplify a complex reality, and they are based on subjective social values, such as disability weight and age weight. Uncertainties need to be known by the decision-makers, as well as, the occurrence of multi-causalities, co-morbidities and inconsistencies of the cause-effect ${ }^{19,20}$. In developing countries such as Brazil, these difficulties are even greater since the health surveillance programs, the morbidity data, and the environmental monitoring strategies are not well established.

In the specific case of assessing the impacts of maternal exposure to $\mathrm{MeHg}$, it considered the neurodevelopment damage of the fetus only. Thus, other health effects, such as damage to the cardiovascular system were not evaluated. Furthermore, the only health outcome considered is the loss of IQ, but the impairment of the neurological system is larger than the loss of intelligence and can reach other brain areas. Another limitation of the approach used, it is to disregard the child loss of IQ, and hence the development of the MMR, due to other maternal risk factors such as: alcoholism, thyroid malfunction, malnutrition and exposure to lead ${ }^{11,26}$.

The IQ losses affect directly the productivity of a country. The IQ gains, which could come from the $\mathrm{Hg}$ pollution control, can be converted into impacts on the economy. The assumption is the benefits of a population with high IQ levels. Griffiths et al. ${ }^{60}$ reported the gains associated with the reduction of environmental emissions of Hg. While, Pichery et al. ${ }^{61}$ estimated that for every 1.0-point IQ lost, due to lead exposure, an equivalent of $€ 17.363$ is lost. The loss of intelligence not only compromises the academic growth of the individual, but also causes the decrease in life expectancy, generates antisocial behavior, and increases the trends of crime ${ }^{11}$.

The estimates of burden of disease attributable to different sources of pollution are important tools for the formulation of public health policies and for the management of public resources available for health activities and services. These estimates are needed to raise awareness about some risks associated with environmental pollution and can be the basis for policy actions.

Despite the severity of the damages potentially caused by $\mathrm{Hg}$ to the humankind, no public policy, aimed to reduce $\mathrm{Hg}$ emissions and human exposure, have been formulated in Brazil yet. This reality stresses the importance of studies, like the present one, that analyze the $\mathrm{Hg}$ exposure problem quantitatively and produce clear and straightforward data for decision makers and society to take action, and address this very important global health issue. 


\section{Collaborations}

ACS Vasconcellos - $\mathrm{PhD}$ responsible for the development of the research project and the preparation of the manuscript; PRG Barrocas - Coorientador and supervisor of the research; DS Mourão - Project holder, responsible for collecting hair samples in the field; CMV Ruiz - Scholar of the research project, responsible for the analysis for the determination of mercury in the samples collected. SS Hacon - Advisor and coordinator of the research project.

\section{References}

1. Blacksmith Institute. World's Worst Pollution Problems. The new top six toxic threats: a priority list for remediation. New York: Blacksmith Institute; 2015.

2. Hacon S, Barrocas PR, Vasconcellos AC, Barcellos C, Wasserman JC, Campos RC, Ribeiro C, Azevedo-Carloni FB. An overview of mercury contamination research in the Amazon basin with an emphasis on Brazil. Cad Saude Publica 2008; 24(7):1479-1492.

3. Bastos WR, Gomes JP, Oliveira RC, Almeida R, Nascimento EL, Bernardi JV, de Lacerda LD, da Silveira EG, Pfeiffer WC. Mercury in the environment and riverside population in the Madeira River Basin, Amazon, Brazil. Sci Total Environ 2006; 368(1):344-351.

4. Lechler PJ, Miller JR, Lacerda LD, Vinson D, Bonzongo JC, Lyons WB, Warwick JJ. Elevated mercury concentrations in soils, sediments, water, and fish of the Madeira River basin, Brazilian Amazon: a function of natural enrichments? Sci Total Environ 2000; 260(13):87-96.

5. Gilmour CC, Henry EA. Mercury methylation in aquatic systems affected by acid deposition. Environ Pollut 1991; 71(2-4):131-169.

6. International Programme on Chemical Safety (IPCS). Methylmercury. Geneva: World Health Organization, IPCS; 1990. (Environmental Health Criteria 101).

7. Dorea JG, Donangelo CM. Early (in uterus and infant) exposure to mercury and lead. Clin Nutr 2006; 25(3):369-376.

8. Hong YS, Kim YM, Lee KE. Methylmercury exposure and health effects. J Prev Med Public Health 2012; 45(6):353-363.

9. Grandjean P, Satoh H, Murata K, Eto K. Adverse effects of methylmercury: environmental health research implications. Environ Health Perspect 2010; 118(8):11371145.

10. Mergler D, Anderson HA, Chan LH, Mahaffey KR, Murray M, Sakamoto M, Stern AH; Panel on Health Risks and Toxicological Effects of Methylmercury. Methylmercury exposure and health effects in humans: a worldwide concern. Ambio 2007; 36(1):3-11.

11. Grandjean P, Landrigan PJ. Neurobehavioural effects of developmental toxicity. Lancet Neurol 2014; 13(3):330-338.

12. Grandjean P, Herz KT. Methylmercury and brain development: imprecision and underestimation of developmental neurotoxicity in humans. Mt Sinai J Med 2011; 78(1):107-118.

13. Cohen JT, Bellinger DC, Shaywitz BA. A quantitative analysis of prenatal methyl mercury exposure and cognitive development. Am J Prev Med 2005; 29(4):353365.

14. Korbas M, O’Donoghue JL, Watson GE, Pickering IJ, Singh SP, Myers GJ, Clarkson TW, George GN. The chemical nature of mercury in human brain following poisoning or environmental exposure. ACS Chem $\mathrm{Neu}$ rosci 2010; 1(12):810-818.

15. Vasconcelos MM. Mental retardation. J Pediatr (Rio J) 2004; 80(2 Supl.):S71-82.

16. Murray CJ, Lopez AD. Evidence-based health policy lessons from the Global Burden of Disease Study. Science 1996; 274(5288):740-743. 
17. Murray CJ, Lopez AD, Jamison DT. The global burden of disease in 1990: summary results, sensitivity analysis and future directions. Bull World Health Organ 1994; 72(3):495-509.

18. Barker C, Green A. Opening the debate on DALYs (disability-adjusted life years). Health Policy Plan 1996; 11(2):179-183.

19. Polinder S, Haagsma JA, Stein C, Havelaar AH. Systematic review of general burden of disease studies using disability-adjusted life years. Popul Health Metr 2012; 10(1):21.

20. Knol AB, Petersen AC, van der Sluijs JP, Lebret E. Dealing with uncertainties in environmental burden of disease assessment. Environ Health 2009; 8:21.

21. Freitas Fonseca M, Torres JPM, Malm O. Interferentes ecológicos na avaliação cognitiva de crianças ribeirinhas expostas a metilmercúri: o peso do subdesenvolvimento. Oecol Brasil 2007: 11(2):277-296.

22. Poulin J, Gibb H. Assessing the environmental burden of disease at national and local levels. Geneva: World Health Organization; 2008.

23. Prüss A, Corvalán CF, Pastides H, De Hollander AE. Methodologic considerations in estimating burden of disease from environmental risk factors at national and global levels. Int J Occup Environ Health 2001; 7(1):5867.

24. Axelrad DA, Bellinger DC, Ryan LM, Woodruff TJ. Dose-response relationship of prenatal mercury exposure and IQ: an integrative analysis of epidemiologic data. Environ Health Perspect 2007; 115(4):609-615.

25. World Health Organization (WHO). Women and health: today's evidence tomorrow's agenda. Geneva: WHO; 2009.

26. Bellinger DC. Prenatal Exposures to Environmental Chemicals and Children's Neurodevelopment: An Update. Saf Health Work 2013; 4(1):1-11.

27. Bose-O’Reilly S, McCarty KM, Steckling N, Lettmeier B. Mercury exposure and children's health. Curr Probl Pediatr Adolesc Health Care 2010; 40(8):186-215.

28. National Research Council (NRC). Toxicological effects of methylmercury. Washington: NRC; 2000.

29. Mathers CD, Murray CJ, Ezzati M, Gakidou E, Salomon JA, Stein C. Population health metrics: crucial inputs to the development of evidence for health policy. Popul Health Metr 2003; 1(1):6.

30. World Health Organization (WHO). Guidance for identifying populations at risk from mercury exposure. Geneva: WHO; 2008.

31. Hacon S, Yokoo E, Valente J, Campos RC, Silva VA, Menezes AC, Moraes LP, Ignotti E. Exposure to mercury in pregnant women from Alta Floresta-Amazon basin, Brazil. Environ Res 2000; 84(3):204-210.

32. Santos EC, Jesus IM, Brabo ES, Loureiro EC, Mascarenhas AF, Weirich J, Câmara VM, Cleary D. Mercury exposures in riverside Amazon communities in Pará, Brazil. Environ Res 2000; 84(2):100-107.

33. Monrroy SX, Lopez RW, Roulet M, Benefice E. Lifestyle and mercury contamination of Amerindian populations along the Beni river (lowland Bolivia). J Environ Health 2008; 71(4):44-50.

34. Dórea JG, Souza JR, Rodrigues P, Ferrari I, Barbosa AC. Hair mercury (signature of fish consumption) and cardiovascular risk in Munduruku and Kayabi Indians of Amazonia. Environ Res 2005; 97(2):209-219.
35. Barbieri FL, Cournil A, Gardon J. Mercury exposure in a high fish eating Bolivian Amazonian population with intense small-scale gold-mining activities. Int J Environ Health Res 2009; 19(4):267-277.

36. Santos EC, Câmara VM, Jesus IM, Brabo ES, Loureiro EC, Mascarenhas AF, Fayal KF, Sá Filho GC, Sagica FE, Lima MO, Higuchi H, Silveira IM. A contribution to the establishment of reference values for total mercury levels in hair and fish in amazonia. Environ Res 2002; 90(1):6-11

37. Yokoo EM, Valente JG, Sichieri R, Silva EC. Validation and calibration of mercury intake through self-referred fish consumption in riverine populations in Pantanal Mato-grossense, Brazil. Environ Res 2001; 86(1):88-93.

38. Kehrig HA, Malm O, Akagi H, Guimarães JR, Torres JP. Methylmercury in fish and hair samples from the Balbina Feservoir, Brazilian Amazon. Environ Res 1998; 77(2):84-90.

39. Barbosa AC, Silva SR, Dórea JG. Concentration of mercury in hair of indigenous mothers and infants from the Amazon basin. Arch Environ Contam Toxicol. 1998; 34(1):100-105.

40. Santos EC, Câmara VM, Brabo ES, Loureiro EC, Jesus IM, Fayal K, Sagica F. Mercury exposure evaluation among Pakaanóva Indians, Amazon Region, Brazil. Cad Saude Publica 2003; 19(1):199-206.

41. Dolbec J, Mergler D, Sousa Passos CJ, Sousa de Morais S, Lebel J. Methylmercury exposure affects motor performance of a riverine population of the Tapajós river, Brazilian Amazon. Int Arch Occup Environ Health 2000; 73(3):195-203.

42. Fréry N, Maury-Brachet R, Maillot E, Deheeger M, de Mérona B, Boudou A. Gold-mining activities and mercury contamination of native amerindian communities in French Guiana: key role of fish in dietary uptake. Environ Health Perspect 2001; 109(5):449-456.

43. Santos EC, Jesus IM, Brabo ES, Loureiro EC, Mascarenhas AF, Weirich J, Câmara VM, Cleary D. Mercury exposures in riverside Amazon communities in Pará, Brazil. Environ Res 2000; 84(2):100-107.

44. Boischio AA, Henshel D. Fish consumption, fish lore, and mercury pollution--risk communication for the Madeira River people. Environ Res 2000; 84(2):108-126.

45. Lebel J, Mergler D, Branches F, Lucotte M, Amorim M, Larribe F, Dolbec J. Neurotoxic effects of low-level methylmercury contamination in the Amazonian Basin. Environ Res 1998; 79(1):20-32.

46. Fillion M, Lemire M, Philibert A, Frenette B, Weiler HA, Deguire JR, Guimarães JR, Larribe F, Barbosa Júnior F, Mergler D. Visual acuity in fish consumers of the Brazilian Amazon: risks and benefits from local diet. Public Health Nutr 2011; 14(12):2236-2244.

47. Passos CJ, Mergler D, Fillion M, Lemire M, Mertens F, Guimarães JR, Philibert A. Epidemiologic confirmation that fruit consumption influences mercury exposure in riparian communities in the Brazilian Amazon. Environ Res 2007; 105(2):183-193.

48. Barbosa AC, Jardim W, Dórea JG, Fosberg B, Souza J. Hair mercury speciation as a function of gender, age, and body mass index in inhabitants of the Negro River basin, Amazon, Brazil. Arch Environ Contam Toxicol 2001; 40(3):439-444. 
49. Barbieri FL, Gardon J. Hair mercury levels in Amazonian populations: spatial distribution and trends. Int $J$ Health Geogr 2009; 8:71.

50. Leite I, Valente J G, Schramm JMDA, Daumas RP, Rodrigues RDN, Santos MDF, Mota JCD. Carga de doença no Brasil e suas regiões, 2008. Cad Saude Publica 2015; 31(7):1551-1564.

51. Schramm JM, Oliveira AF, Leite I, Valente JG, Gadelha ÂMJ, Portela MC, Campos MR. Transição epidemiológica e o estudo de carga de doença no Brasil. Ciência \& Saúde Colet, 2004; 9(4):897-908.

52. Oliveira AF, Costa Leite I, Valente JG. Carga Global das doenças diarreicas atribuíveis ao sistema de abastecimento de água e saneamento em Minas Gerais, Brasil, 2005. Cien Saude Colet 2015; 20(4):1027-1036.

53. Oliveira AFD, Valente JG, Leite IDC, Schramm JMD, Azevedo AS, Gadelha AMJ. Global burden of disease attributable to diabetes mellitus in Brazil. Cad Saude Publica 2009; 25(6):1234-1244.

54. Steckling N, Bose-O'Reilly S, Pinheiro P, Plass D, Shoko D, Drasch G, Bernaudat L, Siebert U, Hornberg C. The burden of chronic mercury intoxication in artisanal small-scale gold mining in Zimbabwe: data availability and preliminary estimates. Environ Health 2014; 13:111.

55. Caravanos J, Dowling R, Téllez-Rojo MM, Cantoral A, Kobrosly R, Estrada D, Orjuela M, Gualtero S, Ericson B, Rivera A, Fuller R. Blood lead levels in Mexico and pediatric burden of disease implications. Ann Glob Health 2014; 80(4):269-277.

56. Norman R, Mathee A, Barnes B, van der Merwe L, Bradshaw D, South African Comparative Risk Assessment Collaborating Group. Estimating the burden of disease attributable to lead exposure in South Africa in 2000. SAMJ 2007; 97(7):773-780.

57. Fewtrell LJ, Prüss-Ustün A, Landrigan P, Ayuso-Mateos JL. Estimating the global burden of disease of mild mental retardation and cardiovascular diseases from environmental lead exposure. Environ Res 2004; 94(2):120-133.

58. Kuno R, Roquetti MH, Becker K, Seiwert M, Gouveia $\mathrm{N}$. Reference values for lead, cadmium and mercury in the blood of adults from the metropolitan area of Sao Paulo, Brazil. Int J Hyg Environ Health 2013; 216(3):243-249.

59. Nilson SA, Costa M, Akagi H. Total and methylmercury levels of a coastal human population and of fish from the Brazilian northeast. Environ Sci Pollut Res Int 2001; $8(4): 280-284$

60. Griffiths C, McGartland A, Miller M. A comparison of the monetized impact of IQ decrements from mercury emissions. Environ Health Perspect 2007; 115(6):841847.

61. Pichery C, Bellanger M, Zmirou-Navier D, Glorennec P, Hartemann P, Grandjean P. Childhood lead exposure in France: benefit estimation and partial cost-benefit analysis of lead hazard control. Environ Health. 2011; 10:44.

Artigo apresentado em 11/06/2016

Aprovado em 22/11/2016

Versão final apresentada em 24/11/2016 
